Prusaczyk Artur, Bogdan Magdalena, Szafraniec-Buryło Sylwia, Żuk Pawel, Guzek Marika, Oberska Joanna. Scope and measurement of the effectiveness of primary patients' care. Journal of Education, Health and Sport. 2022;12(2):209-218. eISSN 2391-8306. DOI http://dx.doi.org/10.12775/JEHS.2022.12.02.023

https://apcz.umk.pl/JEHS/article/view/JEHS.2022.12.02.023

https://zenodo.org/record/6324799

The journal has had 40 points in Ministry of Education and Science of Poland parametric evaluation. Annex to the announcement of the Minister of Education and Science of December 21, 2021. No. 32343. Has a Journal's Unique Identifier: 201159. Scientific disciplines assigned: Physical Culture Sciences (Field of Medical sciences and health sciences); Health Sciences (Field of Medical Sciences and Health Sciences). Punkty Ministerialne z 2019 - aktualny rok 40 punktów. Zalącznik do komunikatu Ministra Edukacji i Nauki z dnia 21 grudnia 2021 r. Lp. 32343. Posiada Unikatowy Identyfikator Czasopisma: 201159. Przypisane dyscypliny naukowe:Nauki o kulturze fizycznej (Dziedzina nauk medycznych i nauk o zdrowiu); Nauki o zdrowiu (Dziedzina nauk medycznych i nauk o zdrowiu).

The The Authors 2022;
This article is published with open access at Licensee Open Journal Systems of Nicolaus Copernicus University in Torun, Poland

Open Access. This article is distributed under the terms of the Creative Commons Attribution Noncommercial License which permits any noncommercial use, distribution, and reproduction in any medium, provided the original author (s) and source are credited. This is an open access article licensed under the terms of the Creative Commons Attribution Non commercial license Share alike. (http://creativecommons.org/licenses/by-nc-sa/4.0/) which permits unrestricted, non commercial use, distribution and reproduction in any medium, provided the work is properly cited. The authors declare that there is no conflict of interests regarding the publication of this paper.

Received: 20.02.2022. Revised: 28.02.2022. Accepted: 02.03.2022.

\title{
Scope and measurement of the effectiveness of primary patients' care
}

Artur Prusaczyk MD, Centrum Medyczno-Diagnostyczne w Siedlcach, Medical and Diagnostic Center in Siedlce, artur.prusaczyk@centrum.med.p1

Magdalena Bogdan PhD, Zakład Medycyny Społecznej i Zdrowia Publicznego, Warszawski Uniwersytet Medyczny, Department of Social Medicine and Public Health, Medical University of Warsaw, mbogdan@wum.edu.pl

Sylwia Szafraniec-Buryło, Zakład Farmakoekonomiki, Instytut Matki i Dziecka, Department of Pharmacoeconomics, Institute of Mother and Child,

Pawel Żuk MD, Centrum Medyczno-Diagnostyczne w Siedlcach, Medical and Diagnostic Center in Siedlce, pawel.żuk@,centrum.med.pl

Marika Guzek Msc, Centrum Medyczno-Diagnostyczne w Siedlcach, Medical and Diagnostic Center in Siedlce, marika.guzek@,centrum.med.p1

Joanna Oberska, Zakład Medycyny Społecznej i Zdrowia Publicznego, Warszawski Uniwersytet Medyczny, Department of Social Medicine and Public Health, Medical University of Warsaw, joannaoberskaa@gmail.com

\footnotetext{
Abstract

Effectiveness of medical care is one of the most reliable parameters to assess individual aspects of the health care system. However, it should be emphasized that there is no unified definition of effectiveness in health care, on the basis of which these aspects can be assessed and compared.

The aim of the study was to draw attention to the inability to make a reliable and authoritative assessment of effectiveness in health care due to the lack of a uniform definition and to emphasize their importance in the light of international comparative analysis.

A review of the literature relating to the assessment of the quality and effectiveness of services provided by healthcare entities was performed.
} 
It has been defined that efficiency grows as the quality of healthcare increases and/or the cost of healthcare decreases, and effectiveness measurement should refer to a specific member of a medical stuff.

Key words: efficiency, effectiveness, health care quality, medical care, effectiveness measurements

\section{Introduction}

Effectiveness is one of the most reliable parameters for the assessment of individual aspects of the healthcare system. However, it should be emphasized that there is no uniform definition of effectiveness in health care that could be used to evaluate and compare those aspects, or even entire health systems. The aim of the study was to draw attention to the inability to make a reliable and authoritative assessment of effectiveness in health care due to the lack of a uniform definition and to emphasize their importance in the light of international comparative analysis.

\section{Current state of the research on the topic}

It is worth starting a discussion about the effectiveness of primary patients' care with the concept of quality. A central focus on quality has been recognized as the most important success factor by the managers of 100 best hospitals in the United States, which had been listed in the annual ranking Ceo Insight 100 Top Hospitals. The focus is an intentional, passionate and systematic creation of quality, which leads to the achievement of new levels year after year' ${ }^{1}$ The World Health Organization defines health care quality as 'the extent to which health services for individuals and populations increase the likelihood of meeting expectations related to treatment outcomes and conform to current professional knowledge' (WHO, 2006). According to the American Joint Commission on Accreditation of Healthcare Organizations, quality means the degree to which each service provided to the patient and delivered in accordance with the current state of knowledge increases the likelihood of obtaining the desired healthcare outcome and reduces the likelihood of adverse effects ${ }^{2}$. The definition of the quality of health services presented above is of particular importance for the primary health care due to capitation payments. Entities which offer high-quality are chosen by the patients more frequently and thus receive higher financing.

For a proper understanding of healthcare quality, it is important to distinguish two components: the quality of medical services and patient satisfaction. This is because a defined standard of the quality of health services does not necessarily imply customer satisfaction (Donabedian et al., 1998). A technical aspect of quality refers to the correctness of providing a medical service in accordance with the current knowledge and existing standards. A functional aspect refers to the effect of the treatment process as perceived by the patient, patient satisfaction, and values important to the patient (Czerw et al., 2012). Patient satisfaction is therefore a dimension of the quality that goes beyond the technological process itself and it is related to the cultural elements that accompany it. Patients assess the quality of medical services based on their observations of the place, staff behaviour or medical equipment (Wiercińska et al., 2012). Recovery affects patient satisfaction, but not in all health care products it is possible to assess the quality of the result by measuring the correctness of the performance of procedures or diagnosis (Lisiecka-Biełanowicz, 2015). Effectiveness of

\footnotetext{
${ }^{1} 100$ Top Hospitals Ceo Insights: keys to success and FUTURE challenges, Thomson Reuters 2011.

${ }^{2}$ https://www.jointcommission.org [access on 13.07.2019].
} 
primary care was also a subject of systematic reviews and meta-analyses (Keleher $\mathrm{H}$ et al, 2009, Winpenny EM et al, 2017 and Freund T et al, 2010).

In Poland, there is a clear distinction between the studies on the two areas of quality analysis presented above. The outcome of treatment is brought into focus when the entire healthcare entities are assessed through an external audit, which results in accreditation, certification or confirmation of ISO standards. Accreditation is a voluntary assessment based on agreed and explicit criteria, and it is performed by independent external auditors ${ }^{3}$. ISO standards are technical standards and relate to the quality management in a medical entity ${ }^{4}$. The quality of the entire health system is also assessed by referring to the health status of the entire population. Assessment of the quality as seen by the patients is measured in questionnaire studies, in which patients express their opinion about a given entity or a particular doctor.

\section{Efficiency and effectiveness of health care}

Health care quality understood as health care clinical effectiveness can be better identified thanks to the approach known as Evidence Based Medicine. The idea behind this concept is integrating individual clinical knowledge and external evidence on the effectiveness of a given procedure. Individual clinical knowledge is proficiency obtained through clinical experience and clinical practice, which manifests itself in making appropriate diagnoses and empathetic approach to the individual situation of the patient when making clinical decisions ${ }^{5}$. Evidence on the effectiveness of a given procedure comes from clinically relevant studies. The two components interact because the evidence cannot be properly used without clinical practice, and clinical practice itself will never be as effective as when it is combined with the latest research results (Sacket et al., 1996).

Value Based Healthcare (VBH) is an extension of the Evidence Based Medicine. It takes into consideration an analysis of costs and benefits provided to patients. The value of healthcare is understood as the quotient of the effects that have a real meaning for the patient and the total expenditure in a given healthcare cycle (Porter and Teisberg, 2006). An additional implication of $\mathrm{VBH}$ is the implementation of activities aimed at treating patients, and not the implementation of the treatment process itself.

It can be easily observed that the difference between evidence-based medicine and value-based medicine is an operational expression of the difference between effectiveness and efficiency of healthcare. The adequacy of the concepts of 'value' and 'efficiency' is also manifested in the dual understanding of the efficiency of medical services.'

1) Efficiency perspective. Financing medical services that guarantee the maximum health condition of the population at the given costs. Efficiency can be improved by increasing the number of medical services using given financial resources.

2) Savings perspective. Offering medical services that guarantee a given health condition of the population at minimal costs. The idea is to improve the effectiveness of treatment using the given financial resources (Krok, 2012).

Both the value and effectiveness increase when the quality of care increases or the cost of care decreases. This division is also used by the US National Quality Forum, which defines efficiency as 'a measure of healthcare costs or the expenditure used to achieve a certain level of care' (Suchecka and Owczarek, 2011). This definition of efficiency was used in the study 'Cost-effectiveness in medical practice', designed by members, employees and consultants of Visible Fairness in 2000. In that study, a medical intervention was considered profitable when

\footnotetext{
${ }^{3}$ https://www.cmj.org.pl/akredytacja [accessed on: 13.07.2019]

${ }^{4}$ https://wiedza.pkn.pl/web/wiedza-normalizacyjna/czym-jest-norma [accessed on: 13.07.2019]
} 
it achieved similar results to an alternative intervention, but at a lower cost or, when it showed better results at a similar cost (Ginsburg et al., 2000). A similar approach can be found in Polish studies. Cholewa-Wiktor defines the technical efficiency as 'the production of a certain number of services using the least possible expenditure, or the production of as many services as possible using the given financial resources' (Cholewa-Wiktor, 2014).

When summarizing the definitions of American organizations, Suchecka and Owczarek define the efficiency of medical services as 'an attribute of the health care model that is measured by the relationship between a product of the health care system (output) and the expenditure needed to produce it (input)'. Importantly, the service provider in this definition can be either a medical entity or an individual doctor. Palmer and Togerson present a more operational dimension of this concept. In their opinion, efficiency is the relationship between the input (costs of labour, capital, and equipment) and intermediate or end results. Intermediate results are factors, such as the number of recovered patients or the waiting time before the procedure. The final results include the number of patients saved from death, the number of extended life years, and time free from disease symptoms (Suchecka and Owczarek, 2011). This definition involves a large selection of efficiency factors and shows the relativism of the concept in relation to various stakeholders: society, service providers, intermediaries, and recipients of medical services.

The most important stakeholders of healthcare entities are patients, founders, payers, public administration authorities, employees, trade unions, suppliers, media, service providers, financial institutions, and the local community. The efficiency of a given healthcare professional can be assessed from the perspective of one of these stakeholders. From the perspective of an entity, efficiency can be measured by physical and financial input. The former refers to the working time of a doctor or nurse, and the latter means costs generated for a given work unit. A payer will use another measure, i.e. the total cost. Different results that are obtained when using different cost measures underline the importance of the problem related to the perspective from which effectiveness is measured. Therefore, one way to control the market due to differences in payments received by doctors is to use standard prices. When standard prices are used, the measures presented above reflect both the efficiency of physical inputs (technical efficiency) and the effectiveness of financial inputs (production efficiency) (Suchecka and Owczarek, 2011).

Cost-effectiveness is also important at the level of decision-making among individual medical workers, due to the fact that health care resources are limited, and patient requirements are constantly growing along with the increasingly expensive treatments. These are doctors who make decisions about diagnosis methods and a particular treatment procedure, and the decision-making process is conducted together with the patient. Holistic patient care is the foundation of the integrated care.

A study by Ginsburg, Kravitz, and Sandberg that was conducted in a group of 512 physicians provided data on physicians' approach to reducing the costs of diagnosis and treatment. Participants to the study agreed that there was a legitimate need to reduce costs and that this could be done by individual doctors. The great majority of respondents were of the opinion that physicians should consider cost-effectiveness when deciding about medical interventions for their patients. Interestingly, clinical guidelines that involve costs seem to have positive effects, as they were assessed positively by the doctors. The problem of the implementation of cost-effectiveness seems to be related to the society. Almost all surveyed physicians had met patients who insisted on unnecessary or cost ineffective medical interventions. Half of the patients reacted badly to the idea of performing a cost-effectiveness study, the other half accepted the explanation that the intervention would waste certain resources. As a result physicians agreed on unprofitable interventions. Thus, doctors accept 
the use of the cost-effectiveness criterion, but they are reluctant to apply it (Ginsburg et al., 2000).

\section{Methods}

A systematic search was carried out in two electronic databases (PubMed and Scopus) to identify published studies on the effectiveness of primary patients' care, its scope and measurement methods. Used key words included "efficiency", "effectiveness", "health care quality", "medical care", "effectiveness measurements".

Last search was performed on 16.10.2021. In addition, we reviewed the references of analyzed articles in order to identify additional studies or reports not found by the initial searches.

Considering a commercial and widely discussed nature of the subject, a Google search was performed as a supplementary strategy of identifying articles. First five pages of results were scanned for relevance.

A total of 2576 studies were identified in the search. After assessment of titles and abstracts and later a full text analysis, we decided to include 24 articles.

\section{Results \\ Effectiveness measurements}

A literature review shows that comprehensive effectiveness measurements vary widely and are often quite extensive. They also combine incompatible dimensions, i.e. assessment of the relationship between inputs and outputs, assessment of the degree to which the assumed goals have been achieved by a particular entity, assessment of the degree to which the employees' needs have been satisfied, assessment of the general perception of the organization by the society, assessment of the entity's ability to develop and survive. The indicators used in the measurement of individual dimensions of effectiveness are both quantitative and qualitative, which makes it difficult to combine them into a comprehensive assessment method. The method of effectiveness measurement should therefore first involve a very precise definition of effectiveness by a single medical worker.

Once the efficiency is understood as the relationship between inputs and intermediate outputs, it is worth analysing the inputs themselves, that is, labour, capital, and equipment. Operationally, quality measurement can be expressed in three areas: structure, process, and result (Czerw et al., 2012).

The quality of the structure is measured using hard and soft factors, which are the resources of a medical facility. They include: the number, education, and experience of medical staff; medical apparatus; infrastructure; organizational structure; organizational culture; management styles. These factors are useful in discussing the quality of the functioning of the entire entity and in creating a context for the operation of the medical personnel.

The quality of the process is both a purely technical dimension, including diagnosis and treatment, and a communication dimension, including effective communication, which makes it possible to obtain the necessary data and communicate recommendations. The technical dimension of treatment results from the applied procedures and the individual characteristics of the staff, and it is subject to analysis. Assessment of the quality of the process often includes effective communication between the medical staff and patients.

The quality of the outcome is measured by treatment success rates: mortality, morbidity, complications, side effects, and patient satisfaction. In order to evaluate the work of individual doctors, the concept of self-efficacy can be used. It is included in the basic 
human beliefs on the basis of which all other beliefs are shaped. The sense of self-efficacy correlates with high self-esteem, self-acceptance, and an optimistic attitude. It also creates expectations towards the undertaken actions (Bandura, 1977). The sense of self-efficacy understood this way was operationalized and used in a study by Hulewska, which was conducted to determine the correlation between doctors' assertiveness (defined as empathy) and the sense of self-efficacy, job satisfaction, and stress (Hulewska, 2015).

\section{Discussion}

Apart from the economic assessment of medical entities, the Polish Ministry of Health proposes three categories of effectiveness assessment factors. Structural factors refer to the organization of a medical entity and its financial capabilities. Outcome indicators refer to the achieved treatment effects (e.g. mean hospitalization time, morbidity, mortality). Process indicators evaluate the course of the treatment process, which includes the relationship between the patient and hospital staff (e.g. number of repeat hospitalizations, number of nosocomial infections).

Niemczyk distinguished two measurement methods: a partial and multidimensional method. The first one involves an indicator method. It consists in measuring individual indicators separately. This approach is used in numerous health care rankings, and the indicators themselves are a valuable source of inspiration for creating more complex measurement methods: indexes and models.

Niemczyk presented the DALE indicator method (Disability Adjusted Life Expectancy), which determines life expectancy at birth and corrects it using the information on losses caused by spending time in a health condition that is worse than perfect. Another measurement method involves indicators that are used in the implementation of Lean and Six Sigma methods in the area of health care. Finally, there are indicators of the effectiveness of the health care system, such as: drug expenditure as \% of GDP, share of private expenditure in the total drug expenditure, use of health services presented by the source of financing as $\%$ of GDP in a given country, number of beds per 100,000 inhabitants, the number of specializations per capita lower and higher than the median in the EU countries (Niemczyk, 2014). Pursuant to the scientific literature, the indicator method of measuring the efficiency can be used solely to assess the effectiveness of entities or even entire health systems.

The second group of methods, multidimensional methods, can be divided into index methods and boundary analysis. Index methods (similarly to indicator methods) are used to measure the effectiveness of entities or entire health systems, but they consist in combining indicators into comprehensive indexes. One example is the Euro-Canadian Health Consumer Index, which assesses patient rights, access to information, treatment outcomes, drug availability, waiting times for health services, and Health in Transition (HiT) analysis. An interesting example is the analysis of the competition index of the third party payer system, which uses competitive features on a zero-one basis, such as the largest payer's market share lower than $50 \%$, the possibility of differentiating prices between payers in the basic health insurance, or the possibility of integrating the payer with service providers in the basic health insurance (Niemczyk, 2014).

More complex measurement methods, which are parametric and non-parametric methods, are included in the frontier analysis (Niemczyk, 2014). Parametric methods are used in models with a strictly defined structure, which affects the number of estimated parameters. These methods require knowledge of the parameters, i.e. making assumptions about the form of the production function, which determines the relationship between inputs and outputs (Ćwiakała-Matys and Nowak, 2009). This is why, parametric methods are best suited for cost and income efficiency estimation. In this category, Niemczyk includes regression-based methods, the examples of which are given below: 
- Ordinary Least Squares (OLS),

- Corrected Ordinary Least Squares (COLS),

- Stochastic Frontier Analysis (SFA),

- Thick Frontier Approach (TFA),

- Distribution Free Approach (DFA) (Niemczyk, 2014).

Due to the lack of knowledge of the process structure, and thus the inability to determine the value of the parameters, non-parametric methods of measuring effectiveness are more useful in the research practice. Adapting the structure to the available data, rather than assuming it a priori, significantly increases the flexibility of using this type of measurement methods. Niemczyk lists the following methods:

- Free Disposal Hull (FDH) analysis;

- Nuclear estimators;

- Radial efficiency measures, e.g. Farrell-Debreu efficiency (Niemczyk, 2014).

DEA method (Data Envelopment Analysis) is an important non-parametric method, which is the most suitable for technical efficiency studies. The DEA is based on the assumption made by Charnes, Cooper, and Rhodes according to which the efficiency of every unit can be represented as a ratio of a weighted sum of outputs to a weighted sum of inputs. The efficiency understood in this way is determined for a specific set of objects referred to as DMU (Decision-Making Unit). The DEA method is therefore related to individual people, and allows for the measurement of their individual effectiveness. On the basis of linear programming, the most effective object is selected and marked with a coefficient equal to $100 \%$, and the remaining objects from the examined set are assigned percentages showing the degree of the efficiency of the reference object (benchmark). This object sets the boundary of efficiency, which is also the boundary for the set of production possibilities of the analysed group of facilities. Thanks to the use of such methodology, it is possible to determine the most effective objects in the examined set without the need to determine the functional relationship between inputs and results. A disadvantage of the DEA method is high sensitivity to unusual parameters of the objects that are considered effective (Bartoszewicz and Lelusz, 2016). The difficulty of applying the DEA method is related to the fact that it is problematic in the business practice to attribute a single output to a given input, because individual elements are considered in a process-like manner. Moreover, the focus of this study should be on assessing the effectiveness of individual healthcare workers rather than creating a benchmark to be sought. This is a cognitive study, not an evaluation/applicative study.

An extension of the DEA methodology in the case of panel data analysis is the Malmquist-Lundberg Index, which allows for the analysis of productivity and efficiency of an enterprise, industry or health systems in a predefined time horizon. The structure of the index is based on the Shephard distance measure, calculated as a comparison of the input-output relationship at different times (Niemczyk, 2014).

The study should be extended with the use of the costs of services provided by the medical personnel, considering the fact that the cost of providing a given service is much more difficult to measure than the cost of the functioning of the entire entity or health system. Efficiency measures that are based on non-monetary units (physical inputs) help to find out if a given service could be produced faster and involve fewer medical workers, man-hours or medical materials. From the perspective of economy, a situation when a product is manufactured with minimum investment is referred to as technical efficiency. Efficiency measures based on monetary units (financial outlays) can be used to verify whether the production can be cheaper, and therefore whether the total costs of labour, materials and other costs of production could be reduced. From an economic point of view, these measures refer to the production capacity, where an optimal combination of all inputs and total costs is 
considered (e.g. can a doctor's job be done by a nurse without losing the quality of the product) (Suchecka and Owczarek, 2011). A pilot study was also conducted in Poland (Wiktorzak et al., 2018 and 2019). The main aims of this pilot was to improve the effectiveness of the primary care. However, the above-described methods of assessing effectiveness have not been applied to the medical entities participating in this pilot study the results regarding the effectiveness have not yet been published. The same is true for other pilot studies in Poland (Guzek M et al., 2019 and Wiktorzak K et al, 2019)

\section{Final remarks}

Summarizing the above considerations, it can be concluded that the effectiveness of patient care is not only an important issue from the perspective of economy, but it is also an interesting study area, which is a scientific niche. This scientific area refers to both the definition and measurement of effectiveness.

The analyses presented above made it possible to define the effectiveness of patient care in the context of its efficiency in relation to the costs. Thus, it can be said that efficiency increases along with the increase in the quality of care or the decrease of health care costs.

Considerations presented in this paper allow for the conclusion that the measurement of effectiveness should refer to an individual doctor and nurse, and it should also take into account the weighted sum of the effects and the weighted sum of expenditures incurred by a given medical entity.

As far as the measurement methodology is concerned, it was found that the essence of effectiveness refers to the relationship between total effects (results) of an activity and the expenditure incurred, using the quotient or differential formula. This requires the following:

- use of a consistent, unambiguous, and transparent measure, e.g. such as money,

- identification of measurable inputs and outputs,

- specification of the goals that an entity is trying to achieve,

- clear definition of the stakeholders of the health care system whose goals and criteria of assessing health system should necessarily be included in the final model of effectiveness assessment.

\section{References:}

1. Bandura A. (1977). Self-efficacy: toward a unifying theory of behavioral change. Psychol Rev. 84(2):191-215. doi: 10.1037//0033-295x.84.2.191. PMID: 847061.

2. Bartoszewicz A., Lelusz H. (2016). Idea i kierunki wykorzystania metody DEA do pomiaru efektywności działania gmin - wybrane aspekty. Finanse, Rynki Finansowe, Ubezpieczenia nr 2/2016 (80), cz. 2. p. 217-225. DOI: 10.18276/frfu.2016.2.80/2-23.

3. Cholewa-Wiktor M. (2014). Efektywność w szpitalach publicznych. nr 180, cz. 2 Dokonania współczesnej myśli ekonomicznej: racjonalność - efektywność - etyka. Cz. 2, Podejście praktyczne. p. 44-45.

4. Czerw A., Religioni U., Olejniczak D. (2012), Metody pomiaru oraz oceny jakości świadczonych usług w podmiotach leczniczych. Probl Hig Epidemiol, 93(2): 269-273.

5. Ćwiąkała-Małys A., Nowak W. (2009). Wybrane metody pomiaru efektywności podmiotu gospodarczego, Wydawnictwo Uniwersytetu Wrocławskiego. ISBN 9788322930823. p. 6.

6. Donabedian A. (1988). The quality of care. How can it be assessed? JAMA. 2330;260(12):1743-8. doi: 10.1001/jama.260.12.1743. PMID: 3045356.

7. Freund, T., Kayling, F., Miksch, A. et al. Effectiveness and efficiency of primary care based case management for chronic diseases: rationale and design of a systematic review and meta-analysis of randomized and non-randomized trials 
[CRD32009100316]. _BMC Health Serv Res 10, 112 (2010). https://doi.org/10.1186/1472-6963-10-112

8. Ginsburg M.E., Kravitz R.L., Sandberg W.A. (2000). A survey of physician attitudes and practices concerning cost-effectiveness in patient care. West J Med. 173(6):390-4. doi: 10.1136/ewjm.173.6.390. PMID: 11112752; PMCID: PMC1071190.

9. Guzek M, Szafraniec-Buryło S, Wyrębiak A, Kowalczyk D, Bukato G, Prusaczyk A, Żuk P, Czech M, Kurpas D. The role of primary care physicians and nurses in convincing patients to participate in a colorectal cancer screening program in a Polish coordinated care organization: a questionnaire-based study. MSP 2019; 13, 2: 24-28. DOI: $10.5604 / 01.3001 .0013 .2986$

10. Hauke E. (1995). Poradnik dla zapewnienia jakości w szpitalu. Wskazówki dla praktycznego użytku. Instytut Organizacji Szpitalnictwa im. L. Boltzmanna w Wiedniu.

11. Hulewska A. (2015), Asertywność a stres, poczucie własnej skuteczności i satysfakcja z pracy doświadczane przez lekarzy, Zeszyty Prasoznawcze. T. 58, nr 2 (222), p. 276283.

12. Keleher H, Parker R, Abdulwadud O, Francis K. Systematic review of effectivness of primary care nursing. Internat. Journal of Nursing Practice, 2009; 15:16-24

13. Krok E. (2012). Efektywność w służbie zdrowia widziana przez pryzmat jakości, Instytut Informatyki w Zarządzaniu Wydział Nauk Ekonomicznych i Zarządzania Uniwersytet Szczeciński.

14. Niemczyk W. (2014), Współczesne metody pomiaru efektywności funkcjonowania systemów zdrowotnych. nr 180, cz. 2 Dokonania współczesnej myśli ekonomicznej: racjonalność - efektywność - etyka. Cz. 2, Podejście praktyczne. p. 185-197.

15. Porter M.E., Elizabeth O.T. (2006). Redefining Health Care: Creating Value-Based Competition on Results. Boston: Harvard Business School Press.

16. Sackett D.L., Rosenberg W.M., Gray J.A., Haynes R.B., Richardson W.S. (1996). Evidence based medicine: what it is and what it isn't. BMJ. 312(7023):71-2. doi: 10.1136/bmj.312.7023.71. PMID: 8555924; PMCID: PMC2349778.

17. Sieć Szpitali a polityka jakości w opiece zdrowotnej. $\mathrm{http}: / / \mathrm{www} 2 . \mathrm{mz} \cdot \mathrm{gov} \cdot \mathrm{pl} / \mathrm{wwwmz} / \mathrm{index} ? \mathrm{mr}=\mathrm{q} 101 \& \mathrm{~ms}=\& \mathrm{ml}=\mathrm{pl} \& \mathrm{mi}=\& \mathrm{mx}=0 \& \mathrm{mt}=\& \mathrm{~m}$ $\mathrm{y}=0 \& \mathrm{ma}=07239$ [accessed on: 13.07.2019].

18. Suchecka J., Owczarek K. (2011). Mierniki efektywności usług zdrowotnych w amerykańskim systemie opieki zdrowotnej. Problemy Zarządzania, Vol. 9, nr 3, p. 79

19. WHO (2006). Quality of Care. A process for making strategic choices in health systems. ISBN 9789241563246.

20. Wiercińska A. (2012). Specyfika rynku usług zdrowotnych. Zarządzanie i Finanse 10, nr 2, cz. 2 | 165-176.

21. Wiktorzak K, Szafraniec-Buryło S, Kurpas D. The status of the Primary Health Care Plus pilot project in Poland. MSP 2019; 13, 3: 22-28.

22. Wiktorzak K, Kozieł A, Szafraniec-Buryło SI, Śliwczyński A. How to design and implement integrated care programmes: Coordinated care models and Primary Health Care PLUS project in Poland. International Journal of Integrated Care. 2018;18(s2):397. DOI: http://doi.org/10.5334/ijic.s2397

23. Wiktorzak K, Szafraniec-Buryło S, Jaworska U, Brzozowska M, Wierzba W, Śliwczyński A, Kurpas D; Determinants of developing a pilot of coordinated care model for patients with multiple sclerosis in Poland; MSP 2019; 13, 2: 11-17. DOI: 10.5604/01.3001.0013.0543

24. Winpenny EM, Miani C, Pitchforth E, King S, Roland M. Improving the effectiveness and efficiency of outpatient services: a scoping review of interventions at the primary- 
secondary care interface. Journal of Health Services Research \& Policy_. 2017;22(1):53-64. doi:10.1177/1355819616648982 